\title{
ENTRE MARIDO E MULHER, \\ O ESTADO METE A COLHER: \\ reconfigurando a divisão do trabalho doméstico na Suécia*
}

\section{Carlos Aurélio Pimenta de Faria}

Pelo menos desde a década de 1930, período em que se inicia a longa era de hegemonia do Partido Social-Democrata sobre o cenário político sueco, elementos da chamada "engenharia social" do país, destinada primordialmente a assegurar a redução das disparidades sociais, têm despertado a atenção internacional e gerado um fértil processo de difusão de inovações em políticas públicas. O chamado "sistema sueco de seguridade para os pais", que é um conjunto de direitos e benefícios estruturados com o intuito de minimizar as incompatibilidades entre as exigên-

* Este artigo é uma versão do sétimo capítulo de minha tese de doutorado, defendida no IUPERJ em dezembro de 1997, cujo título é Regulating the family and domesticating the State. The Swedish family policy experience. Agradeço os comentários e sugestões dos profs. Luiz Eduardo Soares, orientador do trabalho, e Stefan Svallfors, co-orientador, bem como o apoio do $\mathrm{CNPq}$, do qual fui bolsista junto à Universidade de Umeå, Suécia. cias do universo do trabalho remunerado e aquelas relacionadas à criação dos filhos, é duplamente ilustrativo neste sentido.

Em 1974, a Suécia tornou-se o primeiro país do mundo a transformar a licença maternidade em um sistema de licença remunerada para ambos os pais, sistema esse que foi arquitetado para induzir os pais (homens) a assumirem um papel mais ativo na criação dos filhos e, também, para fomentar uma partilha mais igualitária das tarefas domésticas pelo casal. Com objetivos nem sempre idênticos, e muitas vezes com reformulações significativas, tais direitos e benefícios foram posteriormente adotados por muitos países do mundo dito desenvolvido. O sistema sueco de seguridade para os pais parece também marcar o início de uma época em que, paralelamente à ênfase dada à redução dos diferenciais econômicos e de bem-estar relativos às classes sociais, a questão de gênero passa a assumir um lugar cada vez mais destacado na agen- 
da pública do país. O grande ingresso das mulheres no mercado de trabalho prenunciava a debilitação do tradicional modelo familiar do provedor e da dona-de-casa, e o Estado sueco começa a implementar políticas formuladas não apenas com o intuito de reduzir as diferenças nas médias salariais e nas condições de trabalho entre homens e mulheres, mas também visando a tornar mais igualitária a divisão de tarefas no âmbito doméstico.

O presente artigo tem por objetivo discutir o impacto de algumas destas políticas implementadas pela social-democracia sueca com o propósito de facilitar o ingresso e a permanência das mulheres no mercado de trabalho, além de fomentar a igualdade de gênero no país. Primeiramente, discute-se o impacto da legislação de 1971, que baniu a tributação conjunta dos casais, tornando compulsórias as declarações de renda individuais, o que, dado o sistema tributário altamente progressivo do país, implicou o estabelecimento de claros incentivos econômicos para que as mulheres participassem do mercado de trabalho. Além disso, o artigo enfoca o chamado "sistema sueco de seguridade para os pais". Serão discutidas com mais detalhes as peculiaridades e as formas de utilização efetiva da licença remunerada para os pais quando do nascimento de uma criança.

Este trabalho pretende ser, assim, uma avaliação de alguns dos principais benefícios do welfare state sueco contemporâneo. Nesta análise, contudo, importa não apenas desvendar a lógica a presidir a implantação desses benefícios, mas também, e principalmente, discutir a sua tradução prática, ou seja, as formas de utilização efetiva dos benefícios, as quais demonstram claramente, pode-se concluir, os distintos fatores socioeconômicos que têm condicionado (e mitigado) o impacto destas políticas. Aos estudiosos brasileiros das políticas sociais interessará não apenas a apresentação e a análise desses importantes mecanismos destinados a fomentar uma divisão mais igualitária do trabalho doméstico (e a garantir $\mathrm{o}$ ingresso e a permanência da mulher no mercado de trabalho), mas também a percepção de que as políticas para a família, ainda que muitas vezes enfatizando distintas formas de pró-natalismo, podem também ser instrumentos para outros fins.

$\mathrm{Na}$ primeira seção, discutimos brevemente o impacto da introdução da tributação individual na
Suécia, analisando seu significado para a concretização do novo paradigma familiar dos dois provedores. Na segunda seção, apresentamos os benefícios e os direitos que compõem o sistema sueco de seguridade para os pais, discutindo, em uma perspectiva internacional comparativa, o seu principal instrumento: a licença remunerada para os pais quando do nascimento dos filhos. Na terceira e última seção, discutimos, a partir de uma análise do modo como, na Suécia, essa licença tem sido compartilhada entre os pais, a eficácia desses benefícios na geração de uma esfera doméstica em que o trabalho não remunerado seja dividido de uma maneira mais igualitária. Tanto essa análise quanto as pesquisas que têm sido desenvolvidas no país acerca da forma como os suecos empregam o seu tempo mostram as dificuldades vivenciadas na hora da tradução das inovações políticas em práticas sociais efetivas.

É necessário alertar, finalmente, que o título deste trabalho, "Entre marido e mulher, o Estado mete a colher", deve ser interpretado de maneira cautelosa. Se ele parafraseia um dito popular brasileiro, parece-nos importante recordar que, a despeito da acelerada americanização do mundo, a chamada esfera privada não desfruta do status de "nicho inviolável" em todas as partes do Ocidente. A noção de limited government, tão caracteristicamente norte-americana não tem, em definitivo, a mesma penetração na Suécia. Na verdade, não tem sido rara a acusação de que, pelo menos em sua época de maior "ousadia", a "engenharia social" sueca, com seus esforços no sentido de "desmercantilizar" os assalariados e de garantir a qualidade de vida dos cidadãos, muitas vezes normatizando o comportamento individual, teria promovido uma excessiva dependência do indivíduo em relação ao Estado e/ou engendrado a "desprivatização" da família (Faria, 1997, 1998a e 1998b).

\section{A tributação individual e o novo paradigma familiar na Suécia}

Quando o incremento da participação das mulheres suecas no mercado de trabalho é analisado de uma perspectiva histórica, a lei de 1939, 
que proibiu a demissão em casos de gravidez, casamento ou nascimento de uma criança, é normalmente considerada um divisor de águas. Entretanto, importantes medidas visando a garantir um espaço para as mulheres no mercado de trabalho já haviam sido implementadas muito antes da ascensão do Partido Social Democrata ao poder, no início da década de 1930. Em 1846, viúvas, divorciadas e solteiras ganharam permissão formal para trabalhar no comércio; em 1859, as mulheres adquiriram o direito de exercer algumas outras profissões, como a de professoras; em 1870, foram admitidas em ginásios privados e, três anos depois, foi-lhes franqueado o acesso a quase todos os cursos superiores; em 1874, as mulheres casadas conquistaram o direito legal de controlar a sua própria renda; em 1901, foi-lhes concedido o direito a uma licença maternidade, não remunerada, de quatro semanas; em 1925, passaram a ter os mesmos direitos que os homens de ingressar no serviço público (com algumas exceções); e em 1927 , as escolas públicas de segundo grau foram abertas às garotas. Antes que a lei de 1939, que assegurava o emprego das mulheres independentemente de sua situação familiar e/ou marital, tivesse entrado em vigor, o direito a uma aposentadoria mínima havia sido garantido tanto para homens quanto para mulheres na Suécia, em 1935 (Statistiska Centralbyrån, 1995).

Comparando a maneira como as mulheres casadas asseguraram o seu direito de ingresso e permanência no mercado de trabalho na Suécia e nos Estados Unidos, Barbara Hobson (1993) mostrou que, a despeito da similaridade dos debates travados nos dois países, os resultados foram radicalmente diferentes. Em ambos os países, o assunto ganhou destaque na agenda política durante a depressão dos anos de 1930 e as propostas que visavam a compelir as mulheres casadas a abandonar o mercado de trabalho eram sustentadas por argumentos similares: o lar ficava fragilizado ou desmoralizado quando a mulher ingressava no mercado de trabalho; essas mulheres estavam ocupando os postos que deveriam ser reservados aos maridos desempregados e às mulheres solteiras; aceitando salários mais baixos, estavam competindo de maneira injusta com os homens.
Ao contrário do que aconteceu nos Estados Unidos, entretanto, na Suécia as querelas acerca do direito das mulheres casadas ao trabalho remunerado resultaram na proteção legal contra a discriminação e não em uma ampliação das restrições de seu acesso ao mercado de trabalho. A lei de 1939, que protegia as mulheres contra a demissão motivada pelo casamento ou pela gravidez, ilustra muito bem a opção sueca por garantir o direito das mulheres casadas ao trabalho remunerado. O que é surpreendente na comparação, ainda de acordo com Hobson, é que, "no início da depressão, no começo dos anos de 1930, as mulheres suecas não estavam nem tão bem organizadas socialmente nem tinham a influência sobre as políticas públicas que o movimento de mulheres da Era Progressiva norte-americana podia ostentar" (1993, p. 400). A chave para a compreensão da diferença nos resultados pode ser encontrada nas peculiaridades da conformação do Estado de bem-estar social na Suécia, mais especificamente na grande relevância alcançada pela chamada "questão populacional". O movimento generalizado de mobilização política e social em torno das medidas que deveriam ser adotadas para conter o declínio constante das taxas de natalidade foi habilmente manipulado pela social-democracia sueca, a qual, alardeando a suposta ameaça do declínio populacional, conseguiu angariar apoio político para a implementação de reformas que se constituiriam em importantes pilares do Estado de bem-estar social do país (Faria, 1997).

As feministas suecas foram capazes de vincular o direito das mulheres casadas ao trabalho [remunerado] às preocupações acerca do declínio das taxas de natalidade, do baixo número de casamentos e da qualidade de vida das famílias suecas. Conseqüentemente, elas foram capazes de transferir a questão das esferas política e econômica, onde elas eram mais fracas, para a esfera doméstica do processo de elaboração de políticas, à qual elas tinham fácil acesso e onde poderiam usar os seus recursos de poder (Hobson, 1993, pp. 401-402).

Se a legislação sueca de 1939 é um marco mesmo que a sua implementação não tenha sido o resultado de uma aceitação consensual dos direitos econômicos das mulheres - quando é pre- 
ciso explicar os índices atuais de participação da mulher sueca no mercado de trabalho, que estão entre os mais altos do mundo, duas outras políticas, adotadas na década de 1970, são de crucial importância: a eliminação da tributação conjunta dos casais e a concessão de "generosos" e flexíveis benefícios de licença remunerada para ambos os pais quando do nascimento (ou adoção) de uma criança. Em 1971, entrou em vigor na Suécia uma lei que tornava compulsória a declaração individual da renda de cada um dos membros do casal. Essa legislação, associada ao sistema de seguridade para os pais e à provisão maciça de serviços públicos de creche (Faria, 1998a), tem sido amplamente reconhecida como um dos principais elementos indutores do ingresso e da permanência das mulheres suecas no mercado de trabalho. Contudo, ainda que o foco de nossa análise seja basicamente a influência das políticas na oferta de trabalho, é importante destacar também alguns aspectos relativos à demanda do mercado.

Durante todo o período do pós-guerra, a Suécia conseguiu manter baixos os níveis de desemprego, sendo que a demanda por mão-de-obra manteve-se relativamente alta. ${ }^{1}$ Em vista da rápida expansão econômica do pós-guerra e do lento crescimento populacional, que levaram, por vezes, a uma acentuada carência de mão-de-obra no país, os empregadores e os policy makers passaram a se defrontar com duas opções possíveis: o incentivo à imigração ou a utilização da força de trabalho das mulheres casadas. ${ }^{2}$ Sundström sintetizou com precisão a busca por uma solução para a carência de mão-de-obra na Suécia:

Como um resultado das mudanças demográficas, a alta demanda por trabalho não poderia ser atendida apenas pelas fontes tradicionais de recrutamento: homens e mulheres solteiras. Conseqüentemente, os empregadores voltaram-se para a força de trabalho dos imigrantes; de 1960 até 1970, o saldo migratório subiu para 234.000. Entretanto, uma vez que as agências governamentais e o público de uma maneira geral se tornaram progressivamente ciosos dos custos sociais da imigração, ganharam apoio político as medidas destinadas a facilitar o engajamento das mulheres casadas no mercado de trabalho. (Sundström, 1991, p. 180). ${ }^{3}$
Entretanto, estaríamos traçando um esboço equivocado dos esforços estatais para encaminhar as mulheres para o mercado de trabalho na Suécia se a insuficiência de mão-de-obra for compreendida como o único ou como o principal elemento a ser equacionado quando da formulação de políticas. As políticas que serão analisadas neste artigo, que podem ser caracterizadas tanto como políticas de emprego quanto como de fomento à igualdade entre os sexos ou como políticas para a família, são altamente indicativas do engajamento do Estado sueco na questão da igualdade de gênero. ${ }^{4}$ Se a igualdade entre homens e mulheres deve ser conquistada, o trabalho remunerado deve ser atraente para as mulheres; nesse sentido, tornar possível a compatibilização entre a maternidade e a participação no mercado de trabalho é certamente uma estratégia política importante.

As mulheres não foram atraídas para o mercado de trabalho apenas em função da carência de mão-de-obra e dos esforços para se garantir uma remuneração idêntica para o mesmo tipo de trabalho, que fizeram o salário feminino médio dobrar entre 1963 e 1978, diminuindo, dessa forma, a discrepância salarial entre homens e mulheres de $28 \%$ para 10\% no mesmo período (Sundström, 1991, p. 179). Várias outras razões ajudavam a justificar as medidas destinadas a influenciar a oferta de trabalho feminino no país. ${ }^{5} \mathrm{O}$ "incentivo" dado às mulheres para que ingressassem no mercado de trabalho significava, também, oferecer-lhes uma renda própria no presente, reduzindo sua dependência em relação à renda do marido/companheiro. ${ }^{6}$ Deve-se recordar, ainda, que, por meio do trabalho remunerado, a mulher passa a ter direito a uma aposentadoria própria, capaz de sustentá-la na velhice (Gustafsson, 1984).

Antes que a tributação individual compulsória entrasse em vigor na Suécia, a combinação de um sistema tributário altamente progressivo com a declaração conjunta dos casais punia rigorosamente as famílias em que o homem e a mulher trabalhavam fora. Até 1970, tanto os casais legalmente casados quanto aqueles que viviam em união não formalizada tinham seus impostos nacionais e locais calculados com base na adição 
das rendas, o que significava ganhos líquidos bastante baixos para a segunda renda, usualmente a auferida pela mulher, especialmente para aquela cujo marido/companheiro tinha um salário mais elevado.7 "Essa tributação conjunta baseava-se na premissa de que um casamento é uma unidade econômica e que a capacidade de recolher impostos de um dos membros do casal não poderia ser determinada independentemente da renda e dos recursos do outro" (Baude, 1979, p. 155).

O impacto econômico da implementação da tributação individual fica claro no seguinte exemplo: se ambos os cônjuges tinham uma remuneração/hora equivalente àquela de um trabalhador médio da indústria manufatureira, o homem trabalhando em horário integral e a mulher trabalhando meio expediente, a taxa marginal que incidia sobre a remuneração da mulher, em 1970, quando da vigência da tributação conjunta, era de 55\%. Após a reforma tributária, em 1971, essa taxa caiu para $32,5 \%$. Note-se, entretanto, que esse exemplo superestima a renda e os impostos das mulheres, uma vez que aquelas que trabalhavam no setor manufatureiro na Suécia recebiam, em 1970, em média 85\% do salário horário médio (Sundström e Stafford, 1992). ${ }^{8}$

É certo que o cálculo estritamente racional das vantagens que uma dona-de-casa tem ao ingressar no mercado de trabalho deve também incluir, entre outros elementos, a disponibilidade ou não de serviços públicos de creche e a possibilidade de que a renda adicional venha a elevar a renda familiar total para patamares superiores àqueles que permitem à família pleitear o auxílio moradia (ou o direito a um aluguel subsidiado, benefício disponível em alguns casos, na Suécia). Pode-se também perguntar se a introdução da tributação individual serviu como incentivo para que as mulheres passassem a trabalhar em tempo integral ou parcial. ${ }^{9}$ Está além de nossas possibilidades, neste artigo, tentar medir o peso desses fatores na decisão das mulheres. Ademais, essa decisão dependerá, entre outros fatores, das políticas implementadas, das condições do mercado de trabalho, de padrões culturais, do grau de instrução e da idade da mulher. ${ }^{10}$

Importa sublinhar aqui o fato de a tributação individual estar também calcada no princípio de que cada indivíduo, independentemente do sexo, deve ser autônomo e capaz de sustentar a si mesmo, o que contrasta com o sistema tributário anterior, que se baseava e, em larga medida, sustentava o modelo de família do provedor e da donade-casa (Liljeström, 1978). Além disso, quando há a possibilidade de escolha para a mulher, esta não envolve apenas o trabalho remunerado e o não remunerado, mas, freqüentemente, a maternidade e a vida profissional. Na Suécia, um "generoso" sistema de seguridade familiar foi arquitetado e implementado exatamente para evitar que a mulher passasse a ser apenas supostamente igual ao homem (trabalhando em tempo integral, por toda a vida) ou que ela ficasse eternamente restrita às funções domésticas tradicionais.

Se a tributação individual serviu de incentivo para que as mulheres ingressassem no mercado de trabalho, como verificado em uma série de estudos, Juster e Stafford mostraram que a combinação da tributação individual com um sistema tributário altamente progressivo também parece fazer com que os casais passem a dividir o serviço doméstico de maneira mais igualitária (1991). Entretanto, é possível afirmar que uma divisão mais igualitária das tarefas domésticas é, em grande medida, um impacto não esperado, um "efeito colateral" da introdução da tributação individual. O mesmo, contudo, não pode ser dito a respeito do desenvolvimento do sistema sueco de seguridade familiar, o qual, além de tornar compatíveis a maternidade e o trabalho remunerado, também foi inequivocamente desenhado para induzir os pais a assumirem um papel mais ativo na criação dos filhos e no compartilhamento das tarefas domésticas. Se, de acordo com Sandqvist, a tributação individual "pode ser considerada a primeira manifestação legal do novo paradigma familiar" (1987, p. 146), as políticas analisadas a seguir constituem uma espécie de "manifesto oficial" do novo paradigma familiar em que tanto o homem quanto a mulher passam a ser provedores, paradigma esse sancionado pelo Estado e consagrado pela prática social. ${ }^{11}$ Os direitos e os benefícios que compõem o sistema sueco de seguridade para os pais serão apresentados na próxima seção, que também faz uma comparação 
dos benefícios suecos com aqueles disponíveis em outros países industrializados.

\section{O sistema sueco de seguridade para os pais em uma perspectiva internacional}

Uma das mais importantes características do mercado de trabalho sueco durante os anos de 1970 foi o drástico aumento da proporção de mães de crianças em idade pré-escolar que passaram a optar pelo trabalho remunerado (Sundström, 1991). Em 1960, 17\% das mulheres casadas que tinham filhos nessa idade estavam empregadas; a proporção aumentou para 64\%, em 1975, e para 84\%, em 1984 (Sandqvist, 1987, p. 147). Essa mudança, a despeito de suas justificativas socioculturais e de tendências similares detectadas em muitos outros países industrializados, deve também ser interpretada como decorrência da implementação de políticas desenhadas para facilitar a compatibilização da maternidade com o trabalho remunerado. Nesse sentido, torna-se fundamental um exame mais detido dos benefícios e da dinâmica do sistema sueco de seguridade para os pais.

Se os analistas tendem a concentrar sua atenção no programa de licença remunerada para os pais, é importante apresentar, ainda que de maneira sucinta, alguns dos outros benefícios complementares disponíveis no país, cujo propósito também é satisfazer as demandas dos pais trabalhadores e as necessidades relativas a seu duplo papel, como provedores de assistência aos filhos e como assalariados (ou provedores dos recursos materiais). Os principais benefícios que constituem o sistema sueco de seguridade para os pais (föräldraförsäkring) são os seguintes:

- Auxilio gravidez (Havandeskapspenning): se uma mulher grávida tem um emprego que é fisicamente estressante, ela tem o direito de solicitar sua transferência para outra função. Se o empregador não puder fazer a transferência ou se a capacidade de trabalho da mulher estiver reduzida em um quarto ou mais, ela tem o direito a uma licença remunerada (ou auxílio gravidez) de no máximo cinqüenta dias. ${ }^{12}$ Auxílios proporcionais podem ser concedidos no caso de redução das horas de trabalho. O valor do benefício é calculado da seguinte maneira: $65 \%$ do SGI diário da grávida durante os primeiros três dias de licença (SGI - Sjukpenninggrudande inkomst $=$ auxílio doença bási$\mathrm{co}=$ renda pessoal anual antes do desconto dos impostos) e 80\% do SGI durante os outros 47 dias.

- Auxílios para os pais (Föräldrapenning): após o nascimento do filho ou a adoção de uma criança que ainda não tenha dez anos, os pais têm direito a uma licença remunerada de até um máximo de 450 dias (quinze meses). A licença é sujeita à tributação, sendo considerada quando dos cálculos para a aposentadoria. Os pais podem escolher quando tirar a licença remunerada, mas o benefício não é mais concedido após a criança ter terminado o primeiro ano da escola compulsória, o que geralmente acontece aos onze anos de idade. Se ocorrerem nascimentos múltiplos, os pais têm direito a mais 180 dias de licença no caso de gêmeos, a mais 360 dias no caso de trigêmeos e assim por diante. A forma de usufruir a licença pode variar: por tempo integral, por meio expediente ou apenas durante um quarto da jornada diária de trabalho. Quando os pais têm a custódia conjunta da criança, cada um tem direito à metade do total dos dias de licença remunerada. Se um dos pais não tiver condições de cuidar da criança, devido a doença, incapacidade física ou outras razões similares, o outro tem direito a todo o período de licença remunerada. Também é possível transferir a licença remunerada para o parceiro(a), garantindo-se, entretanto, trinta dias que são intransferíveis; essa transferência deve ser formalizada junto ao escritório do seguro social mais próximo. Pais solteiros têm direito a todos os 450 dias de licença.

- Esse auxílio para os pais pode ser concedido antes do nascimento da criança para compensar o fato de o auxílio gravidez não ser concedido durante os dez dias que precedem o parto e/ou para que os pais possam freqüentar cursos de puericultura e congêneres. Após o nascimento, o auxílio para os pais é pago para aquele que toma conta da criança. Ambos os pais podem receber o auxílio simultaneamente, relativo a meio expediente de licença, se assim desejarem.

- O auxílio é concedido a todos os pais, quer eles estejam empregados ou não. Entretanto, os pais 
que não estavam empregados antes do nascimento da criança têm direito apenas a um valor fixo (60 Coroas por dia, em 1995, o que equivalia a aproximadamente U\$D 8,50), enquanto os outros têm direito a benefícios proporcionais à renda. Em 1995, o auxílio concedido durante a licença para os pais era calculado de acordo com as seguintes regras: durante os primeiros 360 dias, a mãe ou o pai recebia $80 \%$ de seus rendimentos brutos anteriores até um teto de 7,5 basbelopp (que é o "Índice de Preços ao Consumidor Modificado", que serve como um valor de referência no sistema de seguridade social sueco) $;{ }^{13}$ os noventa dias restantes eram remunerados com um valor fixo (60 Coroas por dia). Somente aqueles pais que houvessem trabalhado no mínimo oito meses consecutivos antes do nascimento da criança teriam direito a auxílios proporcionais à renda. A remuneração durante os primeiros trinta dias de licença gozados por cada um dos pais era de 90\% da renda bruta (esses dias não são transferíveis). Pais solteiros tinham direito a sessenta dias com benefício de 90\% da renda.

- Resumindo, em 1995, os pais de uma criança recém-nascida na Suécia tinham direito a dez meses de licença com um benefício de $80 \%$ da renda bruta anterior e a um mês não transferível para cada pai, cujo benefício era de 90\%, mais três meses compensados com o valor fixo (60 Coroas diárias) (Sundström, 1996, p. 77).

- Auxílios temporários para os pais (Tillfällig Föräldrapenning): quando a criança ou a pessoa que geralmente toma conta dela está doente, os pais têm direito a uma licença remunerada por um máximo de sessenta dias anuais por criança, período esse que, excepcionalmente, pode ser prolongado até 120 dias. O benefício está disponível até que a criança atinja os doze anos de idade. Se a criança tem necessidade de cuidados especiais, o auxílio temporário pode ser estendido até que a criança tenha dezesseis anos. Os benefícios auferidos também são proporcionais à renda. Em 1995, os primeiros catorze dias da "licença para cuidar de uma criança doente" eram compensados com $80 \%$ dos rendimentos daquele que se licencia. Do $15^{\circ}$ dia em diante, a compensação é de
90\%. Também nesse caso, os pais podem escolher a forma de usufruir os benefícios: em tempo integral, por meio expediente ou apenas durante um quarto da jornada diária de trabalho. É necessário apresentar um atestado se a criança permanecer doente por mais de sete dias.

- Dias de contato" (Kontaktdagar): a fim de visitar a creche ou a escola dos filhos, os pais suecos têm direito a dois dias anuais de licença remunerada por criança, desde que a criança tenha de quatro a doze anos de idade. Ambos os pais podem usufruir o benefício simultaneamente.

- Licença paternidade: os pais suecos têm direito a uma licença paternidade de dez dias após o nascimento ou adoção de uma criança. Esses dez dias de licença remunerada não podem ser concedidos depois de sessenta dias que a criança, saída da maternidade, estiver em casa.

A licença maternidade após o nascimento da criança, com compensação monetária proporcional aos rendimentos, é um benefício previsto em lei na Suécia desde 1955; essa licença maternidade original, de três meses, foi estendida para seis meses em 1962. Em 1974, a Suécia tornou-se o primeiro país do mundo a transformar a licença maternidade em um sistema de licença remunerada para os pais, capaz de beneficiar tanto a mãe quanto o pai. Em países como a Áustria, Holanda, Japão e Austrália, por exemplo, legislações similares foram introduzidas apenas no início dos anos de 1990 (OECD, 1995). Nos países nórdicos, os pais passaram a ter direito a compartilhar a licença remunerada após o nascimento da criança nos seguintes anos: Suécia (1974), Noruega e Finlândia (1978), Islândia (1980) e Dinamarca (1984). Na Escandinávia, somente na Suécia e na Noruega uma parte da licença é reservada exclusivamente para o pai (licença remunerada como um direito individual, não apenas como um direito da família); e somente na Suécia (1979) e na Finlândia (1988) os pais de crianças pequenas têm o direito de optar por uma jornada de trabalho de seis horas (com redução proporcional dos salários) (Nordic Council of Ministers, 1994).

Uma avaliação do sistema sueco de licença remunerada para os pais pode certamente se beneficiar com uma breve comparação internacional. A 
Tabela 1

Programas de Licença Remunerada para os Pais nos Países Nórdicos

\begin{tabular}{|c|c|c|c|c|c|}
\hline & $\begin{array}{l}\text { Dinamarca } \\
\text { (1994) }\end{array}$ & $\begin{array}{l}\text { Finlândia } \\
\text { (1993) }\end{array}$ & $\begin{array}{l}\text { Islândia } \\
\text { (1994) }\end{array}$ & $\begin{array}{l}\text { Noruega } \\
(1993)\end{array}$ & $\begin{array}{l}\text { Suécia } \\
(1993)\end{array}$ \\
\hline $\begin{array}{l}\text { Período máximo de licença } \\
\text { em semanas, das quais: }\end{array}$ & 28 & 44 & 26 & $42 / 52^{(3)}$ & 64 \\
\hline $\begin{array}{l}\text { - Tempo reservado exclusivamente } \\
\text { para a mãe }\end{array}$ & 18 & 18 & 4 & 9 & $-{ }^{(4)}$ \\
\hline $\begin{array}{l}\text { - Tempo reservado exclusivamente } \\
\text { para o pai }\end{array}$ & - & - & - & 4 & $-{ }^{(4)}$ \\
\hline $\begin{array}{l}\text { - Tempo que pode ser usado pelo } \\
\text { pai ou pela mãe }\end{array}$ & 10 & 26 & 22 & $29 / 39$ & $64^{(4)}$ \\
\hline $\begin{array}{l}\text { Porcentagem do salário recebida } \\
\text { durante a licença }\end{array}$ & (1) & 66 & (2) & $100 / 80^{(3)}$ & $90^{(5)}$ \\
\hline
\end{tabular}

Notas:

(1) Na Dinamarca, a licença é remunerada com um benefício fixo mínimo e/ou por meio de compensação salarial definida por acordo entre empregados e empregadores.

(2) Na Islândia, a licença é remunerada com um benefício fixo mínimo e/ou por meio de compensação salarial definida por acordo entre empregados e empregadores. Os servidores públicos têm compensação de $100 \%$ do salário durante a licença.

(3) Na Noruega, os pais podem escolher entre 42 semanas de licença com 100\% de compensação pelas perdas salariais ou 52 semanas com 80\% de compensação, até um teto máximo.

$\left.{ }^{(}\right)$A partir de 1995, um mês da licença passou a ser reservado exclusivamente para a mãe e um mês para o pai.

(5) Em 1993, o sistema sueco tinha as seguintes regras: 51 semanas com benefício de 90\% do salário e treze semanas com benefício fixo. Em 1995, o nível de compensação financeira foi rebaixado para 80\% do salário, mas os meses reservados exclusivamente para o pai e para a mãe continuaram a ser compensados com 90\%. Em 1996, o nível de compensação foi rebaixado ainda mais (para 75\%) e os meses reservados passaram a ter benefício de $85 \%$.

Fonte: Nordic Council of Ministers, 1994, p. 39.

Tabela 1 mostra que, no que concerne à duração dos benefícios e aos níveis de compensação, o sistema sueco é o mais "generoso" entre aqueles disponíveis nos países nórdicos.

No entanto, quando a licença sueca é comparada a benefícios similares disponíveis em outros países da OCDE (Organização para a Cooperação e o Desenvolvimento Econômico), por exemplo, o resultado é mais ambíguo. A comparação não sistemática feita a seguir pretende mostrar que, se o programa sueco de licença remunerada para os pais não é, de uma perspectiva mais ampla e independentemente dos critérios de avaliação, o mais "generoso", ele é, com certeza, um dos mais flexíveis e adequados quando se pensa nas necessidades das famílias em que tanto o pai quanto a mãe estão engajados no mercado de trabalho. Apresentamos dados de um estudo da OCDE englobando doze Estados-membros (Alemanha, Áustria, Bélgica, Canadá, Dinamarca, Finlândia, França, Itália, Japão, Noruega, Reino Unido e Suécia) (OECD, 1995).

Com relação à duração máxima dos benefícios (em janeiro de 1995), os países que ofereciam licenças remuneradas mais longas do que a sueca, de 64 semanas, eram: Áustria e Alemanha (104 semanas); Finlândia (benefício básico durante 26 semanas; benefício estendido até que a criança tenha três anos de idade); França (até que a criança tenha três anos de idade); e Bélgica (260 semanas não comparável diretamente. É importante observar que, dos doze países analisados, somente os 
programas da Alemanha, Finlândia e Suécia cobriam toda a população, não importando se os pais estavam no mercado de trabalho ou não. Na França, por exemplo, a licença não é remunerada quando do nascimento do primeiro filho. Em muitos países, os autônomos, assim como os desempregados, não têm direito ao benefício. Na Áustria, Bélgica, Dinamarca e França, a licença para os pais é remunerada com um valor fixo, e na Alemanha a concessão do benefício monetário, que também é fixo, depende de comprovação de carência.

Com relação aos benefícios monetários dos diferentes programas, aqueles países investigados que ofereciam benefícios proporcionais aos rendimentos anteriores à licença eram: Canadá (57\% dos rendimentos semanais médios, até um determinado teto); Finlândia (o nível de compensação pelas perdas salariais do benefício básico é de 66\% dos rendimentos anuais); Itália (30\% dos rendimentos); Japão (25\% dos rendimentos); Noruega (80\% dos rendimentos quando da licença de 52 semanas ou 100\% quando da licença de 42 semanas); Suécia ( $80 \%$ dos rendimentos durante os primeiros dez meses, mais $90 \%$ por dois meses - um de usufruto exclusivo da mãe e outro do pai -, mais um valor fixo durante três meses); e Reino Unido (sistema two-tier; 90\% dos rendimentos durante as primeiras seis semanas, mais um benefício de valor fixo durante as outras doze semanas).

Portanto, uma vez que os países que oferecem licenças remuneradas mais longas do que a sueca têm níveis de compensação financeira mais baixos - a maioria oferece somente benefícios de valor fixo: Alemanha, Áustria, Bélgica e França -, é possivel deduzir que os benefícios suecos sejam dos mais atrativos para os pais trabalhadores. Sabe-se, entretanto, que a real utilização dos benefícios não é determinada apenas pela estrutura do programa e pelo valor do auxílio ou compensação pelas perdas salariais, mas também pelas características socioeconômicas dos pais (OECD, 1995). Além disso, para que o trabalho remunerado e as demandas/aspirações das famílias possam ser combinados de maneira satisfatória, é necessário adotar medidas destinadas a garantir a flexibilidade da jornada de trabalho e a existência de serviços para as famílias, tais como creches, financiados e/ou normatizados pelo poder público.
Está além dos objetivos deste artigo comparar os índices de utilização dos benefícios nos diferentes países; também não será possível fazer uma comparação das legislações nacionais que introduziram jornadas de trabalho flexíveis em conexão com o nascimento dos filhos. Com relação à flexibilidade na utilização das licenças, todavia, algumas breves comparações em nível internacional podem ser traçadas a fim de ilustrar o quanto o sistema sueco de seguridade para os pais está comprometido com uma compatibilização efetiva entre a participação no mercado de trabalho e a paternidade/maternidade.

De acordo com o mencionado estudo da OCDE, na maioria dos países a flexibilização da forma com que se usufrui a licença deu-se paralelamente à extensão progressiva da sua duração máxima. Dois importantes aspectos dessa flexibilização devem ser ressaltados: as possibilidades de se tirar uma licença por tempo parcial e de se transferir o direito à licença da mãe para o pai e vice-versa. Um terceiro aspecto a ser destacado é a possibilidade de se interromper a licença e voltar a gozá-la após algum tempo.

Apesar de muitas regulamentações nacionais incluírem a possibilidade de se tirar a licença por tempo parcial - na Holanda essa é a única possibilidade - isso geralmente depende da concordância do empregador. Somente na França, Finlândia, Noruega e Suécia existe o direito legal à licença parcial. Uma outra opção - disponível na Áustria, Espanha, Finlândia, Noruega e Suécia - é a possibilidade de os pais reduzirem suas horas de trabalho até que o filho inicie a escolarização compulsória (OECD, 1995, p. 179).

É importante lembrar que, na Suécia, o direito dos pais a uma licença parcial significa que eles podem escolher usufruir a licença em tempo integral, por meio expediente ou apenas durante um quarto da jornada diária de trabalho; eles contam também com o direito de optar por uma jornada de trabalho de seis horas (com redução proporcional dos salários). Além disso, têm a possibilidade do fracionamento da licença, caso não queiram ou não possam tirá-la de uma só vez. Essa opção também existe na Alemanha, Dinamarca, Finlândia e Grécia (nos EUA, ela está sujeita à anuência do empregador). 
Ainda de acordo com a OCDE, os países nórdicos "têm os sistemas de licença para os pais mais avançados e flexíveis" (OECD, 1995, p. 189), sendo que, como visto anteriormente, no que concerne à duração dos benefícios e aos níveis de compensação pelas perdas salariais, o sistema sueco é o mais "generoso" deles. Quando a questão é a flexibilidade, também é evidente que o sistema sueco desponta como um dos mais "vantajosos" para famílias em que ambos os pais estão inseridos no mercado de trabalho, dada a possibilidade de se tirar uma licença parcial e/ou fracionada, enquanto na Dinamarca, Finlândia e Noruega, há várias restrições instituídas (para maiores detalhes, ver OECD, 1995, Tabela 5.1).

Porém, quando a análise é deslocada da provisão de benefícios (ou da legislação) para o grau efetivo de sua utilização, torna-se rapidamente evidente que o uso que os pais fazem dos benefícios disponíveis é inferior ao que talvez fosse possível esperar. Já dissemos que não será feita aqui qualquer análise microsociológica comparativa do impacto e da utilização efetiva dos diferentes programas de licença para os pais em vigor; tal tentativa certamente nos afastaria muito dos objetivos deste artigo. Assim, a análise subseqüente concentra-se na maneira como as mães e os pais suecos têm usufruído o sistema de seguridade, discutindo a medida em que essas políticas têm conseguido, efetivamente, reconfigurar as tradicionais atribuições domésticas e profissionais de homens e mulheres.

\section{O sistema sueco de licença remunerada para os pais: moldando o comportamen- to dos pais?}

A estrutura do sistema sueco de licença remunerada apresenta uma solução bastante atrativa para o dilema "maternidade versus trabalho remunerado". Na Suécia, dada a conformação desse sistema, são oferecidos à mulher muitos incentivos para que planeje sua vida de modo a adiar o nascimento (ou adoção) do primeiro filho até que ela tenha atingido uma posição relativamente estável no mercado de trabalho, de tal forma que possa usufruir benefícios mais altos quando da licença.
Contudo, antes que possamos dar início à nossa avaliação do grau de utilização da licença para os pais na Suécia, cuja estruturação tem por objetivo não apenas salvaguardar o direito da mulher ao trabalho remunerado, mas também "definir" (ou "endossar") a configuração de um tipo particular de família, parecem importantes algumas considerações sobre os anos de retração do Estado de bem-estar no país, em meados da década de 1990, que implicaram a redução circunstancial de benefícios tais como aqueles auferidos por meio do sistema sueco de seguridade para os pais.

A recessão do início dos anos de 1990 não levou somente à interrupção do padrão incrementalista de melhoria paulatina dos benefícios sociais suecos, mas também a um declínio dos índices de fertilidade e de participação da mulher no mercado de trabalho. Até 1994, o nível sueco de compensação pelas perdas salariais quando do usufruto da licença para os pais era de $90 \%$ do salário anterior (na verdade, 90\% do SGI - Sjukpenninggrudande inkomst $=$ auxílio doença básico = renda pessoal anual antes do desconto dos impostos, muito próxima ao salário bruto); em 1995, o nível de compensação foi reduzido para $80 \%$, mas, durante os recém-introduzidos meses de uso exclusivo (um para a mãe e outro para o pai), foi mantido o benefício de 90\%. Em 1996, o nível de compensação foi reduzido ainda mais (para 75\%), e o nível de compensação durante os meses de uso exclusivo caiu para 85\%. Além disso, o valor fixo recebido nos últimos noventa dias da licença permaneceu congelado em sessenta coroas desde 1987, o que significou, é claro, uma desvalorização real dos benefícios, ainda que a inflação do período não tenha sido especialmente elevada.

Ainda não estão claras todas as implicações concretas de tal política de retração, conduzida pela "mesma" social-democracia que erigiu o modelo sueco de estatização da provisão de bem-estar social, mesmo que o declínio das taxas de fertilidade e a diminuição da participação das mulheres no mercado de trabalho já tenham sido registrados. O governo social-democrata do período de retração enfatizava que, a despeito da necessidade de se reduzir o gasto público, seriam preservados os serviços sociais disponibilizados pelo 
Estado. Assim, talvez fosse possível dizer, por exemplo, que parte significativa dos empregos no setor público, para onde as mulheres acorreram em grande número, seria preservada. Talvez também fosse possível alegar que alguns valores estão enraizados tão profundamente na sociedade sueca que a retração dos benefícios provavelmente não influenciaria muito as taxas de fertilidade. Uma pesquisa, por exemplo, mostrou $47,9 \%$ dos entrevistados "concordando firmemente" e outros $38,1 \%$ "concordando" com a afirmação de que "ver os filhos crescerem é a maior alegria da vida" (Edlund, Sundström e Svallfors, 1994). Contudo, a avaliação do impacto das políticas públicas sobre o comportamento individual é sabidamente problemática, especialmente daquelas que acabam por envolver uma gama tão ampla e diversificada de variáveis; assim, associar de forma acrítica os fenômenos descritos acima pode ser uma redução sociológica temerária.

Considerando o impacto do sistema sueco de seguridade para os pais sobre as taxas de fertilidade, o demógrafo Jan Hoem, ao analisar uma regra do sistema de licença para os pais que ainda não mencionamos (o chamado "intervalo de elegibilidade”, isto é, o número máximo de meses entre nascimentos consecutivos que torna possível para as mães reter o nível da compensação financeira da licença anterior), chegou a uma demonstração rara de um efeito causal direto da reforma de uma política sobre o comportamento demográfico (Jan Hoem, 1993). A legislação sobre o "intervalo de elegibilidade" (ou o "prêmio pela rapidez" do nascimento subseqüente - speed premium, como Hoem o denominou) foi alterada da seguinte maneira: quando a licença remunerada foi estabelecida na Suécia, era vantajoso adiar o nascimento de outra criança até que a elegibilidade para a compensação pelas perdas salariais tivesse sido alcançada novamente, por meio da acumulação adicional de renda auferida no mercado de trabalho.

Durante os anos de 1970, um tipo de prêmio pela rapidez (speed premium) foi estabelecido para o nascimento subseqüente. Tornou-se legalmente reconhecido o direito da mãe ou do pai de reter, durante a licença referente a um segundo nasci- mento, o nível de compensação financeira auferido quando da licença anterior, desde que o intervalo entre os dois nascimentos não excedesse o período legalmente garantido da licença mais seis meses. Nesse ínterim, o beneficiário não precisaria ter tido qualquer renda proveniente de sua inserção no mercado de trabalho. Em 1974, o intervalo entre os nascimentos passou a não mais poder exceder os doze meses, mas, na prática, ele podia ser estendido por intermédio de vários mecanismos, tais como a contagem do tempo em que a pessoa tivesse se licenciado por motivos médicos ou que tivesse gozado de férias acumuladas, extensão essa que podia atingir três meses. Nos anos subseqüentes, o intervalo de elegibilidade foi expandido em sintonia com a progressiva extensão da licença para os pais prevista em lei, até atingir um máximo de quinze meses em 1979 (acrescidos de quaisquer férias acumuladas e do eventual período de licença por motivos médicos [...]). Essa extensão do benefício foi transformada em lei e estendida para vinte e quatro meses em 1980; o intervalo de elegibilidade foi ampliado para trinta meses em 1986. (As extensões por incorporação de férias e de licença médica foram eliminadas em 1980.) (Jan Hoem, 1993, p. 27).

Como é comum na Suécia que algumas mães escolham trabalhar durante meio expediente após o término da licença remunerada, o nascimento de outra criança após o fim do período de elegibilidade pode reduzir drasticamente a compensação financeira da mãe durante a licença remunerada subseqüente. Portanto, os casais têm um incentivo econômico bastante significativo para planejar a chegada de seus filhos de acordo com o intervalo de elegibilidade. A tradução prática desse cálculo foi mostrada por Hoem em sua análise da "incidência de um segundo nascimento, tomada por base a idade do primeiro filho" e da "incidência de um terceiro nascimento, tomada por base a idade do segundo filho". Os dados de Hoem mostram como os pais suecos responderam prontamente à legislação relacionada com os níveis de compensação pelas perdas salariais durante a licença, diminuindo o intervalo entre os nascimentos. O fato de a incidência do segundo e do terceiro nascimentos ser mais alta logo após o fim do intervalo de elegibilidade também é significativo: se muitos casais reagiram à regulamentação sobre a elegibilidade diminuindo o intervalo entre os 
nascimentos e garantindo o usufruto de benefícios mais altos, muitos outros falharam, devido às incertezas da concepção e da gravidez. Não obstante, parece claro que aqueles que "falharam" também estavam tentando se beneficiar da legislação vigente.

Portanto, é possível dizer que o sistema sueco de seguridade para os pais é estruturado de tal modo que os casais tenham incentivos para adiar o nascimento do primeiro filho (até que a mulher esteja bem estabelecida no mercado de trabalho) e para programar o nascimento dos filhos subseqüentes de modo a aproveitar o speed premium.

Também parece-nos importante analisar, ainda que brevemente, outras implicações da provisão dos benefícios que compõem o sistema sueco sobre o planejamento da vida profissional das mulheres e a maneira como os pais suecos reagiram à transformação da licença maternidade em licença para os pais.

É interessante recordar que, quando a Suécia se tornou o primeiro país a implementar um sistema de licença remunerada para os pais, em 1974, não existiam os meses de usufruto exclusivo; os pais podiam decidir eles próprios como compartilhar toda a licença. Os meses de uso exclusivo foram introduzidos em $1995 .{ }^{14} \mathrm{Um}$ dos objetivos oficiais do sistema sueco sempre foi fomentar a igualdade entre os sexos; todo indivíduo deveria ter os mesmos direitos à independência econômica através do engajamento no mercado de trabalho, à participação e influência na sociedade e nos assuntos públicos e à oportunidade de cuidar de seus próprios filhos. Em busca da igualdade entre homens e mulheres, a Suécia, sem negligenciar as questões relativas ao mercado de trabalho e à participação política, parece ter devotado especial atenção à família. Hwang sumarizou da seguinte maneira a perspectiva adotada pelos policy makers:

Esperava-se que as mulheres fossem economicamente independentes de seus parceiros e tão responsáveis quanto eles pelo suporte econômico dos filhos. Os homens deveriam ser igualmente responsáveis pelo trabalho doméstico e pelos cuidados com as crianças. A divisão de tarefas na família era vista como um pré-requisito para a plena participação das mulheres na economia, na política e nos sindicatos e como um modo de au- mentar as oportunidades de auto-realização dos homens como pais e como pessoas que têm interesses outros além daqueles relacionados ao mercado de trabalho (Hwang, 1987, p. 120).

Com relação à licença remunerada para os pais quando do nascimento de uma criança, projetada para ser um mecanismo de ponta naquela "revolução silenciosa", deve-se notar que, se quase todas as mães suecas têm se beneficiado da licença, os índices de utilização dos benefícios pelos pais têm sido consistentemente baixos. ${ }^{15}$ Freqüentes campanhas publicitárias, financiadas pelas agências públicas que gerenciam os benefícios sociais, foram lançadas no país, mostrando homens engajados em atividades tipicamente masculinas, como lutadores e jogadores de futebol, cuidando e alimentando seus filhos. Apesar desses esforços, no início dos anos de 1980 apenas cerca de 10\% dos pais faziam uso de uma parte da licença durante os primeiros 180 dias, e somente $2 \%$ dos dias de licença eram tirados pelos pais. Tal distribuição talvez possa ser justificada pelo fato de a maioria das mães amamentarem seus bebês durante os primeiros seis meses. No entanto, quando se considera o resto do período de licença remunerado com benefícios proporcionais à renda, percebe-se que apenas 28\% dos pais haviam usufruído a licença. A porcentagem dos dias de licença usufruídos pelos homens era somente $9 \%$ do total no início dos anos de 1980; os últimos noventa dias da licença, que são remunerados com um valor fixo, quase nunca eram usados. Quando o primeiro ano após o nascimento é considerado como um todo, notase que quatro de cada cinco pais não tiraram a licença nem por um único dia. Em tal período, os pais usaram somente $4 \%$ do total dos dias de licença remunerada, enquanto $96 \%$ do tempo era usado pelas mães (Hwang, 1987, pp. 127-128).

Os índices de utilização da licença pelos homens, entretanto, aumentaram ao longo da década de 1980. O National Social Insurance Board (Riksförsäkringsverket) investigou como os pais suecos de crianças nascidas em 1989 usaram a licença nos anos de 1989 e 1990 (Riksförsäkringsverket, 1993). Verificou-se que $44 \%$ deles tinham recorrido aos benefícios durante o período. A investigação é particularmente interessante por mostrar como o grau de 
utilização dos benefícios varia significativamente entre segmentos sociais distintos. As constatações dessa pesquisa podem ser resumidas da seguinte forma:

- Há uma diferença entre os índices de utilização da licença por pais casados e por aqueles que vivem em união não chancelada oficialmente. $45 \%$ dos homens casados e $49 \%$ daqueles do segundo grupo usufruíram a licença remunerada no período. Note, entretanto, que os pais casados tiraram um número médio de dias de licença mais alto (cinqüenta dias, enquanto a média do segundo grupo foi de 44 dias).

- Quanto mais velho o pai, maior o número médio de dias de licença tirados. O oposto acontecia com as mães: quanto mais jovens, mais longa a licença. Surpreendentemente, foram os casais jovens (ambos entre vinte e vinte e quatro anos de idade) aqueles que dividiram a licença de forma mais desigual.

- Quando a criança tinha atingido um ano de idade, 38\% dos pais (homens) casados e 44\% daqueles que viviam em uniões não chanceladas oficialmente tinham recebido auxílios monetários referentes à licença.

- Quanto maior o nível educacional do pai e de sua esposa/companheira, mais comum era que o pai tirasse a licença. 51\% dos homens haviam tirado licença quando ambos os pais freqüentaram escola de nível superior, enquanto somente $34 \%$ dos homens o fizeram quando ambos os pais tinham apenas a educação compulsória. A porcentagem de mães que tiraram a licença não foi influenciada por seu próprio nível educacional, nem, tampouco, pelo nível educacional de seus maridos/companheiros. O mesmo acontece quando o número de dias de licença remunerada é considerado. É importante observar, ainda, que o grupo que compartilhou a licença de maneira mais igualitária (aquele em que ambos os pais freqüentaram o ensino superior) dividiu o período de licença da seguinte maneira: os pais tiraram uma média de 58 dias e as mães uma média de 335 dias.

- O grau de utilização da licença pelos homens varia de acordo com as áreas de atuação pro- fissional. Mais de 50\% dos pais que estudaram pedagogia ou enfermagem fizeram uso dos benefícios, enquanto um pouco mais de um terço dos pais que estudaram engenharia florestal ou agronomia o fizeram.

- A licença foi utilizada por uma porcentagem maior de pais que trabalhavam no setor público (57\%), quando comparados àqueles do setor privado (48\%). Além disso, o fato de a mãe ser funcionária pública ou estar engajada no setor privado parece também ter influenciado os índices de utilização dos benefícios pelos pais. 52\% dos pais cujas esposas/companheiras eram funcionárias públicas fizeram uso do benefício, contrapondo-se a $47 \%$ daqueles cujas esposas/companheiras eram empregadas do setor privado (esse padrão foi percebido desde o início dos anos de 1980). A porcentagem de mães que utilizou os benefícios não foi influenciada pela distinção entre pertencimento ao setor público ou ao privado. No entanto, as mães empregadas no setor privado tiraram licenças mais longas.

- Ainda não foi mencionado neste trabalho o fato de que, a despeito de todos os esforços governamentais e do relativo sucesso das políticas desenhadas para fomentar a igualdade de gênero em várias áreas, a Suécia continua tendo, entre os países desenvolvidos, um dos mercados de trabalho mais segregados segundo o sexo (veja, por exemplo, Jonung, 1984). No que concerne à licença para os pais, o mercado de trabalho sueco, fortemente segregado, parece influenciar os índices de utilização dos benefícios. Entre as quinze ocupações/profissões em que é mais comum que os pais (homens) tirem licença, não se encontra nenhuma das trinta ocupações que são mais claramente "dominadas" pelos homens. É muito mais comum que os pais que exercem funções usualmente "dominadas" pelas mulheres (por exemplo, homens que trabalham como professores da pré-escola, enfermeiros etc.) tirem a licença.

- Percebeu-se, também, uma relação entre a faixa de renda dos pais e os índices de utilização da licença. O padrão descoberto é, porém, contraditório em relação à correlação existente entre 
os índices de utilização e o grau de instrução. Os pais (homens) que têm renda mais baixa são aqueles que tiram as licenças mais longas (uma média de 58 dias), enquanto pais de renda média tiram uma média de 44 dias da licença. Aqueles que têm renda alta tiram licenças um pouco mais longas que esse último grupo. As mães, entretanto, não seguem esse padrão. Mães que têm renda alta tiram uma média de 284 dias de licença, enquanto aquelas com uma renda média tiram 326 dias, em média, e aquelas que têm renda baixa tiram aproximadamente esse mesmo número médio de dias.

- A pesquisa conduzida pelo National Social Insurance Board mostrou, também, que 48\% dos pais (homens) suecos fizeram uso da licença, enquanto somente $30 \%$ dos imigrantes oriundos de países outros que não os nórdicos o fizeram. Até mesmo a origem das mães parece influenciar os índices de utilização da licença pelos pais. $48 \%$ dos pais casados ou vivendo com mulheres suecas gozaram da licença remunerada, enquanto apenas 33\% daqueles casados ou vivendo com mulheres de países não nórdicos o fizeram. No entanto, quando foi analisada a extensão da licença gozada, verificou-se que os pais iranianos, por exemplo, tiraram uma média de oitenta dias, enquanto os suecos tiraram 48 .

Essas constatações evidenciam a influência tanto do mercado de trabalho quanto de fatores socioculturais nos índices de utilização da licença. Tendo por base os dados mencionados acima, é possível sugerir algumas explicações importantes. É possível deduzir, por exemplo, parte das razões que fazem com que pais mais velhos tirem licenças remuneradas mais longas do que os mais jovens. Em um contexto de crescimento econômico continuado e de baixo índice de desemprego, parece razoável supor que os trabalhadores mais experientes tenham uma posição mais consolidada no mercado de trabalho. Assim, talvez seja factível imaginar que pais mais velhos tenham maiores incentivos para tirar licenças mais longas, uma vez que a maior parte dos benefícios auferidos durante a licença é proporcional à renda. O fato de mães mais jovens tenderem a tirar licenças mais longas talvez possa ser explicado não tanto pelo nível de compensação pelas perdas salariais durante o período de afastamento, mas pela possibilidade de que seu padrão de utilização possa ser influenciado por uma lógica distinta: mães mais jovens podem estar seguindo um tipo peculiar de "estratégia de adiamento", qual seja: se o filho chega antes de elas terem atingido uma posição mais favorável no mercado de trabalho, pode ser uma estratégia racional o adiamento, por um período maior de tempo, da luta por uma melhor posição no mercado de trabalho. ${ }^{16}$ A surpreendente constatação de que os casais mais jovens (2024 anos) formam o grupo que compartilha a licença para os pais de maneira mais desigual pode ser explicada de forma similar: os pais jovens (homens) podem estar por demais preocupados em melhorar sua posição no mercado de trabalho para se "dar o luxo" de gozar licenças mais longas. Note, entretanto, o fato óbvio de a adoção de tal cálculo implicar a reprodução da tradicional divisão de tarefas entre o casal.

No que tange à correlação entre o grau de instrução, a renda e os índices de utilização da licença pelos pais, padrões interessantes podem ser percebidos. Se quanto mais alto o grau de instrução do casal, mais freqüente é que o pai tire a licença, ${ }^{17}$ a porcentagem de mães que tiram a licença não é influenciada nem pelo seu próprio nível educacional nem pelo de seus maridos/companheiros. O mesmo é válido no que concerne à duração da licença gozada pelas mães. ${ }^{18}$ Quando se presta atenção à duração média da licença tirada pelo grupo menos desigual (composto por famílias em que ambos os pais freqüentaram escola de nível superior), torna-se evidente que atingir um compartilhamento mais equilibrado das funções domésticas entre homem e mulher ainda parece uma utopia distante na Suécia: nesse grupo, os pais (homens) tiraram uma média de 58 dias de licença remunerada, enquanto as mães tiraram uma média de 335 dias. Do ponto de vista da igualdade de gênero, a assimetria na utilização dos dias de licença parece indicar não apenas as dificuldades no compartilhamento mais igualitário da tarefa de provisão doméstica de atenção à criança. Quando se observa o grau de engajamento dos casais suecos no trabalho remunerado e no não remunerado - o que será discutido mais adiante -, 
fica claro que a tradicional divisão de tarefas ainda prevalece, a despeito de todos os esforços governamentais e dos elevadíssimos índices de participação da mulher sueca no mercado de trabalho.

A interpretação que estamos desenvolvendo pode ser brevemente interrompida neste ponto, para uma curta digressão a respeito dos padrões de utilização da "licença temporária" e dos "dias de contato", padrões esses que não são dissonantes do modo como homens e mulheres têm compartilhado a licença para os pais quando do nascimento de um filho. Durante a década de 1980, a porcentagem de homens que usufruíram a licença temporária variou entre 42,8\% (1980) e 39,7\% (1984), o que mostra que, na Suécia, é muito mais freqüente as mulheres permanecerem em casa quando os filhos adoecem. Quando se examina a duração média da licença temporária, essa divisão desigual torna-se ainda mais evidente. ${ }^{19}$ No que diz respeito à utilização dos "dias de contato" (para que os pais visitem a creche ou escola dos filhos - dois dias por ano para cada filho entre quatro e doze anos de idade), o mesmo padrão assimétrico é encontrado. Em 1987, 34\% daqueles que utilizaram os "dias de contato" eram homens. Em 1986, essa modalidade de licença foi tirada apenas para menos de $12 \%$ das crianças, sendo que a maior parte delas iniciava a sua vida escolar (Näsman, 1992, p. 12).

Retomando a discussão sobre o compartilhamento da licença, é importante destacar que a investigação conduzida pelo National Social Insurance Board também mostrou que os pais (homens) que tinham renda mais baixa tiraram licenças mais longas, enquanto aqueles que tinham renda média ou alta tiraram licenças menores. $\mathrm{O}$ padrão de utilização dos benefícios pelas mães é um pouco diferente: aquelas que tinham renda alta tiraram licenças mais curtas, enquanto as que tinham renda média ou baixa tiraram licenças maiores, sendo muito pequena a diferença entre esses dois últimos grupos. A lógica do mercado de trabalho talvez possa explicar as diferenças: aqueles empregados em setores competitivos e/ou cujos empregos envolvem um grau mais elevado de responsabilidade - sendo o absenteísmo, conseqüentemente, mais complicado - parecem tirar licenças mais curtas. ${ }^{20}$ Isso significa que, a despeito da compensação proporcional pelas perdas salariais, o vínculo com o mercado de trabalho tem um papel importante no que diz respeito à decisão de se tirar licenças maiores ou menores. O impacto da vinculação ao setor público ou ao privado na utilização diferenciada da licença para os pais parece indicar uma lógica similar.

Vimos que uma maior proporção de pais (homens) empregados no setor público (57\%) tirou licença, enquanto apenas 48\% daqueles empregados no setor privado o fizeram. Os pais empregados no setor público também tiraram licenças mais longas (uma média de 57 dias, comparada com uma média de 43 dias tirados por pais empregados no setor privado). Mesmo o fato de a mãe estar empregada no setor público ou no privado influenciou os índices de utilização da licença pelos pais (homens). A seguinte lógica pode ser sugerida para explicar esses padrões: sabendo que o setor público é usualmente mais "protegido" da pesada competição que normalmente caracteriza o setor privado, e que os servidores públicos podem ser mais conscientes de seus direitos, pode-se sugerir que eles são mais propensos a tirar a licença, tendência essa reforçada pelo fato de que parecem ser maiores as garantias de que eles consigam reassumir o seu trabalho, após a licença, exatamente nas mesmas condições. ${ }^{21}$ Além disso, deve-se também recordar o fato de o setor público sueco não ser estritamente "dominado" pelos homens. Nesse ponto, é importante lembrar que, segundo a pesquisa conduzida pelo National Social Insurance Board, é mais comum que os pais (homens) que trabalham em ocupações tipicamente femininas tirem licença.

A pesquisa em questão mostrou que o pertencimento ao setor público ou ao privado não influencia a porcentagem de mães que usufruem a licença para os pais. Entretanto, por que as mães que trabalham no setor privado tiram licenças mais longas? Se é verdade que a força de trabalho feminina de baixa qualificação é empregada mais freqüentemente no setor privado, pode ser razoável supor que essas mães, cientes da precariedade de suas perspectivas de ascensão profissional, escolham permanecer com seus filhos por um período de tempo mais longo. De fato, em um estudo que compara os padrões de utilização da licença para 
os pais nos países nórdicos, Kaul, não encontrando explicação para as diferenças na utilização da licença na "orientação familiar" da mãe, sugeriu que

[...] as mulheres cujos empregos oferecem condições de trabalho mais precárias desenvolvem poucos vínculos positivos com seu trabalho; sua identidade com o trabalho, assim, torna-se fraca. Vincular sua identidade à importante função de provedora de atenção aos filhos parece oferecer uma estratégia alternativa razoável (Kaul, 1991, p. 121).

De maneira similar, o fato de ser mais freqüente que os pais suecos usufruam a licença do que aqueles nascidos em países não escandinavos pode ser explicado tanto por fatores relacionados ao mercado de trabalho quanto por fatores culturais. Pais iranianos, por exemplo, que não são tão propensos a gozar da licença quanto os suecos, usufruem, no entanto, licenças mais longas. O padrão talvez possa ser explicado pela mesma lógica que utilizamos para tentar decifrar as razões que levam as mães empregadas no setor privado a tirar licenças maiores.

As diferentes taxas de utilização da licença por pais casados e por aqueles que vivem em uniões não chanceladas formalmente ainda precisam de explicação. Por que pais casados tiram licenças mais longas, mas uma proporção maior de pais do segundo grupo tira licença? Não dispomos de dados capazes de sustentar uma explicação convincente. Seria razoável sugerir que os pais casados tiram licenças mais longas porque são mais velhos (e lembre-se que quanto mais velho o pai maior a licença)?

Os dados apresentados e discutidos mostram que os benefícios relacionados à licença para os pais não conseguem fazer com que os homens passem a assumir um papel mais significativo no âmbito doméstico da criação dos filhos, isto é, que os esforços do governo sueco no sentido de promover um compartilhamento mais igualitário das tarefas ainda não tiveram o sucesso esperado. ${ }^{22}$ As persistentes discrepâncias de gênero têm sido também, de maneira similar, detectadas por pesquisas que desvendam o modo como os suecos empregam o seu tempo. Assim, os dados apresentados a seguir, referentes à maneira como os casais suecos dividem, na prática, as suas tarefas cotidianas, parecem reiterar algumas das principais questões que acabamos de discutir. A Tabela 2 mostra como, na Suécia, diferentes grupos, divididos por sexo e de acordo com sua faixa etária e situação familiar, empregam o seu tempo.

Se a carga de trabalho total (remunerado + não remunerado) dos homens e das mulheres é bastante similar na Suécia (ver também Tabela 3), é evidente que as mulheres (em todas as faixas etárias e situações familiares) ainda devotam uma parte significativamente maior de seu tempo ao trabalho não remunerado, enquanto os homens (em todas as faixas etárias e situações familiares) passam a maior parte do seu tempo exercendo atividades relacionadas ao trabalho remunerado. Também fica claro que os homens parecem usufruir um pouco mais de "tempo livre" (com exceção dos homens de meia idade sem filhos). Por outro lado, as mulheres "gastam" mais tempo com "necessidades pessoais". Note que as maiores discrepâncias entre o envolvimento de mulheres e homens com o trabalho não remunerado são encontradas nas categorias "pais com filhos", o que, de certo modo, reflete também o uso diferenciado que pais e mães fazem da licença na Suécia. Também é evidente que os pais trabalham mais do que os outros homens, o que é verdade tanto no que concerne ao trabalho remunerado como no que se refere ao trabalho não remunerado (e os pais de crianças pequenas também estão mais envolvidos com o trabalho não remunerado do que qualquer outro grupo de homens). As mães devotam muito mais tempo ao trabalho não remunerado do que as mulheres jovens ou as mulheres sem filhos. A tabela acima retrata com clareza a persistência de uma divisão tradicional das tarefas entre homens e mulheres, ainda que sejam muito elevadas as taxas de participação da mulher sueca no mercado de trabalho; quando os filhos são mais jovens, a discrepância entre as tarefas exercidas pelos homens e aquelas exercidas pelas mulheres aparece com uma nitidez ainda maior.

Quando se analisa o tipo de atividade que as mulheres e os homens suecos exercem como "trabalho não remunerado", o quadro resultante apenas confirma a persistência de uma divisão de tare- 
Tabela 2

Uso do Tempo Segundo a Idade, o Sexo e a Situação Familiar - Suécia 1990/1991

Distribuição percentual para um dia normal (computado o final de semana), calculada para todos os indivíduos em cada grupo

\begin{tabular}{|c|c|c|c|c|c|c|c|c|c|c|c|c|}
\hline & \multicolumn{2}{|c|}{$\begin{array}{c}\text { Trabalho } \\
\text { Remune- } \\
\text { rado }\end{array}$} & \multicolumn{2}{|c|}{$\begin{array}{l}\text { Trabalho } \\
\text { não Re- } \\
\text { mune- } \\
\text { rado }\end{array}$} & \multicolumn{2}{|c|}{$\begin{array}{c}\text { Educa- } \\
\text { ção }\end{array}$} & \multicolumn{2}{|c|}{$\begin{array}{c}\text { Necessi- } \\
\text { dades } \\
\text { Pessoais }\end{array}$} & \multicolumn{2}{|c|}{$\begin{array}{c}\text { Tempo } \\
\text { Livre }\end{array}$} & \multicolumn{2}{|c|}{$\begin{array}{l}\text { Total } \\
(\%)\end{array}$} \\
\hline & M & $\mathrm{H}$ & M & $\mathrm{H}$ & M & $\mathrm{H}$ & M & $\mathrm{H}$ & M & $\mathrm{H}$ & M & $\mathrm{H}$ \\
\hline Jovens: $20-24$ anos & 15 & 22 & 11 & 7 & 6 & 5 & 44 & 41 & 23 & 24 & 100 & 100 \\
\hline Adultos (25-44 anos) sem filhos & 20 & 24 & 14 & 10 & 2 & 2 & 43 & 41 & 21 & 23 & 100 & 100 \\
\hline Adultos (45-64 anos) sem filhos & 16 & 22 & 18 & 12 & 0 & 0 & 43 & 42 & 23 & 22 & 100 & 100 \\
\hline Pais com filhos entre 0 e 6 anos & 12 & 27 & 28 & 15 & 2 & 1 & 42 & 40 & 16 & 17 & 100 & 100 \\
\hline Pais com filhos entre 7 e 17 anos & 20 & 28 & 19 & 12 & 1 & 1 & 42 & 40 & 17 & 19 & 100 & 100 \\
\hline Média de todos os grupos & 16 & 25 & 20 & 12 & 1 & 1 & 43 & 41 & 20 & 21 & 100 & 100 \\
\hline
\end{tabular}

M = Mulheres; $\mathrm{H}=$ Homens. "Trabalho Remunerado" inclui o tempo de almoço durante os dias úteis e o tempo despendido no trajeto casa-trabalho. "Necessidades Pessoais" incluem o tempo de sono, de descanso, das refeições, dentre outros itens similares.

Fonte: Adaptado de Nordic Council of Ministers, 1994, p. 31.

Tabela 3

Tempo Dedicado ao Trabalho por Pessoas entre 20 e 64 anos de Idade - Suécia 1990/1991 Distribuição percentual por tipo de atividade em um dia normal

\begin{tabular}{lcc}
\hline Tipo de Atividade & Mulheres (\%) & Homens (\%) \\
\hline Trabalho Remunerado & $\mathbf{4 5}$ & $\mathbf{6 7}$ \\
Trabalho Não-Remunerado & $\mathbf{5 5}$ & $\mathbf{3 3}$ \\
\hline Discriminação: & & \\
Trabalho doméstico & 29 & 11 \\
Atenção aos filhos & 8 & 3 \\
Aquisição de bens e serviços & 6 & 4 \\
Reparos e manutenção & 4 & 7 \\
Atenção dispensada a outros & 2 & 2 \\
Outros tipos de trabalho no lar & 1 & 1 \\
Deslocamento relacionado ao trabalho não remunerado & 5 & 5 \\
\hline Volume Total de Trabalho & $\mathbf{1 0 0}$ & $\mathbf{1 0 0}$ \\
\hline Horas e Minutos & $\mathbf{8 : 4 0}$ & $\mathbf{8 : 4 5}$ \\
\hline
\end{tabular}

Fonte: Adaptado de Nordic Council of Ministers, 1994, p. 32. 
fas desigual e determinada pelo gênero (e lembrese que, no que diz respeito ao trabalho remunerado, o sexo também parece determinar as "chances" de uma pessoa trabalhar durante tempo integral ou parcial. Além disso, como mencionado anteriormente, é importante não esquecermos que, entre os países industrializados, o mercado de trabalho sueco é, talvez, surpreendentemente, um dos mais segregados por gênero). A Tabela 3 mostra como a carga de trabalho dos homens e das mulheres é dividida na Suécia, discriminando algumas das principais formas de trabalho não remunerado.

A Tabela 3 evidencia que o trabalho não remunerado é ainda dividido na Suécia de acordo com a tradicional alocação de tarefas entre homens e mulheres. Enquanto as mulheres fazem a maior parte do trabalho doméstico e passam muito mais tempo cuidando dos filhos, fazendo compras e contratando serviços, os "reparos e manutenção" são atividades masculinas de relativo destaque sob a rubrica "trabalho não remunerado". Fica claro que, se o modelo familiar dos dois provedores é hoje preponderante na Suécia, ${ }^{23}$ a desejada transição do modelo familiar do "homem/provedor e da mulher/dona de casa" para um tipo de família capaz de dividir igualmente todas as tarefas permanece como uma utopia. Entretanto, como foi sugerido por Karin Sandqvist, a "distinção sueca entre masculinidade e feminilidade pertence mais ao campo [da distribuição] das tarefas, dos interesses e das áreas de especialização do que ao campo dos valores e da estrutura das personalidades" (1992, p. 91). Contudo, a despeito da persistência de um certo tradicionalismo na divisão das tarefas entre homens e mulheres, não se deve desconsiderar as mudanças sociais em curso no país.

A diferença entre o tempo que mulheres e homens despendem no "trabalho remunerado", retratada na Tabela 3, reflete tanto a maior porcentagem de homens engajados no mercado de trabalho como a maior porcentagem de mulheres trabalhando em tempo parcial. Sabe-se que a entrada das mulheres suecas no mercado de trabalho se deu, em grande medida, pelo regime de tempo parcial. A tendência atual, entretanto, é de que as mães aumentem o número de horas dedi- cadas ao trabalho remunerado e que os pais sigam o caminho inverso (ver, por exemplo, Näsman, 1992). A opção por trabalhar em tempo parcial, como modo de combinar a responsabilidade tradicional das mulheres pela casa e pelas crianças com o novo papel compartilhado de provedoras, foi denominada pela demógrafa Eva Bernhardt de "estratégia de combinação" das mulheres suecas (apud Näsman, 1992). Talvez possa ser sugerido, entretanto, que os pais (homens) suecos, em vez de adotar qualquer tipo particular de "estratégia de combinação", ainda "ajudam com os pratos" ou "passam um tempo com as crianças”. No entanto, uma vez mais é aconselhável examinar a questão de uma perspectiva de longo prazo.

Os dados apresentados nas Tabelas 2 e 3 podem certamente ser interpretados como uma indicação bastante concreta da persistência de uma tradicional divisão de tarefas entre homens e mulheres na Suécia. Na verdade, os debates travados no país, toda vez que se evidencia a discrepância entre o objetivo oficial de fomentar a igualdade de gênero e a relativa falta de elasticidade do comportamento social, tendem a enfatizar as desigualdades atuais mais do que o progresso alcançado. O comportamento dos pais (homens) suecos de duas gerações distintas deve ser comparado para que possamos perceber que não é de todo infundada a sugestão de que a igualdade de gênero na esfera privada talvez já esteja sendo gestada no país, ainda que os resultados não sejam tão tangíveis quanto aqueles registrados em outras esferas. ${ }^{24}$

Duas pesquisas, que se valeram de amostras nacionais abrangentes, mostraram que, em 1957, $14 \%$ dos pais (homens) "ajudavam" a lavar os pratos e 4\% ajudavam a cozinhar; em 1982, 40\% dos pais afirmaram que eles no mínimo dividiam igualmente a tarefa de lavar as louças, enquanto 14\% cozinhavam (apud Sandqvist, 1987, p. 153). Além disso, vários estudos qualitativos têm mostrado que, atualmente, os pais (homens) estão muito mais envolvidos no trabalho doméstico, sentindo-se muito mais responsáveis pela criação dos filhos do que os pais entrevistados em estudos anteriores (ver Sandqvist, 1992). 


\section{Considerações Finais}

Confirmando que, quando a questão é a divisão do trabalho doméstico, a prática social fica muito distante da ideologia na Suécia, a socióloga Linda Haas mostrou que os casais suecos, no entanto, realmente dividem o trabalho doméstico de forma mais igualitária do que os casais norte-americanos (Haas, 1981). Na verdade, vários outros estudos comparativos têm sugerido que os papéis atribuídos a homens e mulheres na Suécia são muito menos diferenciados do que em outros países, pelo menos quando o mercado de trabalho não é levado em consideração (Sandqvist, 1992). Além disso, foi demonstrado por Moen que a probabilidade de sofrer estresse psicológico e fadiga se tornou também mais equivalente entre mães e pais suecos entre os anos de 1968 e 1981, na esteira do grande aumento, no período, da participação das mães suecas no mercado de trabalho. Isso pode indicar também uma divisão mais igualitária das tarefas domésticas entre os membros do casal, o que pode ter sido influenciado pelo sistema sueco de seguridade para os pais (Moen, 1989).

Portanto, se a carga de trabalho dos homens e das mulheres ainda é relativamente mal distribuída na Suécia, vários fatores sugerem uma possível redução tendencial dessas assimetrias: aumento da participação das mulheres/mães no mercado de trabalho (uma tendência que foi interrompida pela recessão do início dos anos de 1990); maior porcentagem de mulheres trabalhando em tempo integral; crescente número de pais (homens) que usufruem a licença quando do nascimento dos filhos, participando, assim, mais ativamente na sua criação; aparente surgimento de um padrão mais igualitário, ainda que longe de ser simétrico, de divisão do trabalho não remunerado entre os membros do casal.

Entretanto, se o sistema de seguridade para os pais implementado na Suécia é bastante "generoso" quando comparado a benefícios similares disponíveis em outras nações industrializadas, propiciando licenças longas, flexíveis e destinadas a suprir necessidades diversas, oferecendo compensações pelas perdas salariais relativamente altas, parece plausível afirmar que a ênfase do sis- tema recai mais sobre a possibilidade de se compatibilizar a maternidade com o trabalho remunerado do que sobre o declarado objetivo de induzir a criação de uma perfeita simetria entre os papéis assignados aos pais e às mães. Argumenta-se, freqüentemente, na Suécia, que uma boa parte dos empecilhos a uma distribuição mais igualitária do trabalho remunerado e do não remunerado desapareceria se a jornada de trabalho de seis horas fosse implementada no país. No entanto, uma vez que tal redução ainda não parece factível, uma política que havia sido orientada inicialmente pela oferta aos pais de incentivos econômicos, seguida de campanhas de "esclarecimento" (isto é, que enfatizava a indução racional e moral da alteração do comportamento individual), começou a mudar em 1995, quando os meses de uso exclusivo foram introduzidos na regulamentação da licença e os níveis de compensação pelas perdas salariais foram reduzidos pela primeira vez. Certamente, "reservar" um mês de licença para o usufruto exclusivo das mães e outro para o usufruto dos pais teria sido uma mudança muito mais retórica se o nível dos benefícios auferidos durante esses meses não tivesse sido preservado.

A resposta do governo social-democrata da Suécia à recessão econômica, materializada na reforma da licença para os pais, foi ambivalente. Se o governo tivesse seguido a opinião pública, os meses de uso exclusivo não teriam sido introduzidos, uma vez que a maioria dos suecos era contra a proposta (ver nota 13). Entretanto, como não havia uma oposição organizada com vistas ao rechaçamento da reforma, e como o Partido Social Democrata (entre outros partidos suecos) estava interessado em cultivar a imagem de um partido sensível às demandas e necessidades da mulher, talvez seja plausível interpretar a reforma tanto como uma mera redução no nível dos benefícios, quanto como uma mudança que significou a adoção de uma posição mais afirmativa em favor da igualdade entre os sexos.

Porém, independentemente dos claros obstáculos à efetivação dos objetivos da "engenharia social" sueca, interpostos pelo mercado de trabalho, pela persistência de práticas sociais que ainda preservam um certo tradicionalismo e pela pró- 
pria perda de capacidade fiscal e regulatória do Estado, as políticas aqui discutidas parecem evidenciar o fato de que, se é verdade que a "longa marcha" pela redução das disparidades salariais e pela implantação da democracia econômica vem sendo relegada a um segundo plano pela socialdemocracia sueca, pelo menos desde a década de 1980, o front de batalha pela igualdade de gênero, aberto na década de 1960, parece hoje concentrar os esforços e a capacidade de inovação que têm tornado plausíveis, no caso dos países escandinavos em geral e no caso da Suécia em especial, denominações como "Estado amigo das mulheres" e caracterizações de um suposto "feminismo de Estado".

\section{NOTAS}

1 É importante ressaltar, ainda, que o pleno emprego foi, ao menos até a década de 1980, uma prioridade na agenda da social-democracia sueca, que tem sido o partido mais votado no país desde as eleições de 1917, a despeito de seu domínio parlamentar só ter se consolidado a partir das eleições de 1932 (Faria, 1996).

2 A limitação propositada da atividade econômica parece uma "opção" que até mesmo o Partido Ambientalista Sueco - Miljöpartiet, fundado em 1981, cogitou apenas cautelosamente em seu período de maior radicalização.

3 Além disso, a carência de mão-de-obra na Suécia foi acentuada pela redução legal da jornada de trabalho. Em 1972, o número de horas semanais dedicadas ao trabalho foi reduzido de 42,5 para 40 horas; em 1976, a idade mínima para a aposentadoria foi rebaixada de 67 para 65 anos; o tempo de férias passou para cinco semanas em 1978, e para 5,5 semanas em 1990 (Sundström, 1991, p. 180).

4 De acordo com Nils Elvander, o debate acerca da tributação individual não foi originalmente conduzido segundo clivagens político-partidárias, mas levado adiante por militantes do movimento feminista. Segundo o argumento, levaria algum tempo até que o Partido Social-Democrata resolvesse dar à questão a importância devida. Gunnar Sträng, o Ministro social-democrata das Finanças, por exemplo, seria convencido da relevância da tributação individual apenas em meados da década de 1960, após repetidas previsões do aumento da carência de força de trabalho no país (apud Gustafsson, 1990). Gustaf Lindencrona, por sua vez, assevera que a necessidade de igualização entre os sexos tornou-se um dos principais argumentos empregados em favor da tributação individual na Suécia (Lindencrona, 1989).

5 Löfström e Gustafsson, em uma avaliação do impacto de algumas inovações das políticas salariais sobre a remuneração das mulheres na Suécia, chegaram à seguinte conclusão: "os salários relativos das mulheres que eram operárias na manufatura cresceram, em média, de 70\% a 90\% entre 1960 e 1985. A presente análise empírica indica que por volta de 50\% desse aumento foi devido a diversas mudanças institucionais. O acordo sobre remunerações idênticas para o mesmo tipo de trabalho (1960) e o direito franqueado às mulheres de trabalhar à noite nas indústrias (1962) parecem ter gerado os maiores efeitos. Ainda resta, entretanto, alguma incerteza quanto aos efeitos do acordo sobre oportunidades iguais para mulheres e homens (1977). Esse estudo indica, assim, que leis e acordos que contribuem para mudanças quantitativas e qualitativas podem ser usados com sucesso para igualizar as condições em geral e os salários de homens e mulheres no mercado de trabalho" (Löfström e Gustafsson, 1990, p. 15).

6 Em um estudo de 1992, que comparava a oferta de trabalho feminino na Suécia e na Holanda, Andersson et al. mostraram que as mulheres suecas eram mais "emancipadas" que as holandesas, uma vez que seu nível de engajamento no mercado de trabalho não era influenciado pela renda do marido (1992).

7 É importante destacar, porém, que a tributação individual havia se tornado opcional já em 1967. A reforma de 1971 a fez compulsória (Moen, 1989, p. 25).

8 Nos Estados Unidos ou na Inglaterra, por exemplo, onde a tributação individual foi introduzida apenas no final dos anos de 1980, o efeito da tributação conjunta sobre o salário das mulheres não era tão perverso, uma vez que os sistemas tributários desses países não eram tão progressivos (Lewis e Åström, 1992, p. 67).

9 Ao longo dos anos de 1970, as taxas marginais sobre a remuneração daqueles empregados em horário integral cresceram acentuadamente, enquanto as taxas daqueles que trabalhavam meio expediente permaneceram relativamente constantes. Assim, 
não deve ser surpreendente o fato de, durante aquela década, a maioria das mulheres ter ingressado no mercado de trabalho assumindo empregos de jornada reduzida. A proporção de mulheres trabalhando em tempo parcial, que era de $38 \%$ em 1970, atingiu um pico de $47 \%$ em 1982. Com a reforma tributária de 1982, que limitou as taxas marginais a um máximo de $50 \%$ para a maioria dos assalariados, o número médio de horas trabalhadas aumentou para os homens e, particularmente, para as mulheres. Uma outra reforma tributária entrou em vigor em 1990, reduzindo ainda mais as taxas marginais (a um máximo de 33\%). De uma maneira geral, pode-se dizer que a oferta de trabalho feminino foi muito mais afetada pelas alterações no salário líquido do que a oferta de trabalho dos homens (Sundström e Stafford, 1992, pp. 204-205). Sobre a popularização entre as mulheres suecas do trabalho em tempo integral durante a década de 1980, ver Sundström, 1993.

10 Note-se que a participação da mulher sueca no mercado de trabalho declina com o aumento da idade (Andersson et al., 1992).

11 Um survey conduzido em 1992 na Suécia mostrou que o modelo familiar dos dois provedores se tornou amplamente reconhecido como um valor tanto por homens como por mulheres, especialmente pelas últimas. Ficou também evidente que o estilo de vida da dona-de-casa não parece mais ser atraente para as suecas (Björnberg, 1993).

12 Consideramos, neste artigo, regras, regulamentos e níveis de compensação salarial vigentes em 1995. A fonte é o livro Vår Trygghet 1995 (Folksam, 1995), que procura esclarecer aos suecos seus direitos sociais, apresentando em detalhes os benefícios disponíveis e as regras de elegibilidade. Até a trigésima edição, de 1995, quase 2,6 milhões de cópias haviam sido vendidas.

13 Em 1985, menos de 1\% das mulheres e menos de $10 \%$ dos homens na Suécia tinham rendimentos maiores do que as 7,5 "basbelopp" (Sundström e Stafford, 1992, p. 213).

14 Note que uma pesquisa conduzida pelo Bureau Central de Estatísticas da Suécia em 1992/1993 mostrou que $55 \%$ das entrevistadas e $60 \%$ dos homens não consideravam positiva a introdução de períodos de uso exclusivo no sistema de licença remunerada (Statistiska Centralbyrån, 1994, tabela 6.3).
15 Quando se trata de compreender a "relutância" dos pais suecos em tirar a licença, é essencial recordarmos que os homens geralmente ganham mais do que as mulheres na Suécia, o que, como será visto, não é a única razão para esse comportamento.

16 Note, entretanto, que outra "estratégia de adiamento" tem sido amplamente reconhecida: adiar o nascimento do primeiro filho para uma idade mais avançada. De acordo com Jan Hoem, "uma fertilidade relativamente alta e em crescimento no grupo de mulheres na faixa dos trinta anos é uma característica proeminente do comportamento recente da família sueca" (1993, p. 22). De fato, no início dos nos de 1990, as mulheres suecas na faixa dos trinta anos de idade apresentavam uma taxa de fertilidade mais alta do que a daquelas na faixa de vinte e poucos anos. Essa tendência significou uma inversão marcante do padrão prevalecente em meados dos anos de 1970, quando o grupo mais jovem apresentava uma taxa de fertilidade duas vezes maior do que a do grupo mais velho (Jan Hoem, 1990). É importante ressaltar que, se essa inversão foi, provavelmente, encorajada pelas campanhas publicitárias lançadas com o intuito de sensibilizar os grupos mais jovens quanto à importância da paternidade responsável e pelo enraizamento de valores como a "auto-realização", ela também parece refletir a estrutura dos benefícios oferecidos pelo sistema sueco de seguridade para os pais.

17 Como salientado por Kaul (1991), mulheres que têm uma posição de maior prestígio no mercado de trabalho podem também usufruir uma situação mais cômoda quando da negociação com seus parceiros sobre a divisão do trabalho familiar. Não se deve negligenciar, ainda, o fato de que, nesses casos, seus recursos de barganha também são, provavelmente, mais desenvolvidos.

18 No que tange à correlação entre o grau de instrução e as taxas de fertilidade, um padrão notável foi detectado na Suécia: mães com alto grau de instrução que têm dois filhos partem para uma terceira gravidez com mais freqüência do que aquelas que têm o mesmo número de filhos mas um menor grau de escolaridade (Britta Hoem, 1993).

19 Note que, durante a década de 1980, a duração média da licença temporária por filho foi bastante estável, sendo de pouco mais de seis dias por ano (Näsman, 1992, p. 12). 
20 Outra pesquisa mostrou que pais (homens) "que ocupavam postos de gerência ou supervisão tinham optado pela licença em tempo integral com menor freqüência do que outros pais" (apud Sundström e Stafford, 1992, p. 209). De acordo com um estudo da OCDE, o "seguinte padrão foi observado nos países nórdicos: a mais alta incidência de retorno ao trabalho após a licença para os pais é encontrada entre mães que tinham empregos que ofereciam boas condições de trabalho e entre aquelas que relatam que seu emprego é importante para elas. Esse último grupo inclui, principal, mas não exclusivamente, mulheres que exercem funções altamente qualificadas. Contrariamente, mulheres que exercem funções subordinadas, particularmente aquelas funções que são tipicamente femininas, retornam menos freqüentemente a seus empregos" (OECD, 1995, p. 188). Note, entretanto, que tem se tornado cada vez mais raro as mulheres suecas abandonarem o mercado de trabalho após o nascimento dos filhos (Näsman, 1992).

21 A fim de minimizar qualquer possibilidade de reação negativa ou punitiva do empregador quando os pais tiram a licença, os "auxílios para os pais", os "auxílios temporários para os pais", os "dias de contato" e a "licença paternidade" são financiadas com recursos provenientes de impostos gerais, sem nenhum custo direto para o empregador do beneficiário. No entanto, uma pesquisa conduzida por Näsman mostrou que $25 \%$ dos pais (homens) entrevistados relataram que tinham encontrado dificuldades no local de trabalho relacionadas ao gozo da licença para os pais. Isso ocorreu muito mais freqüentemente com pais empregados no setor privado, com trabalhadores de colarinho branco em setores gerenciais, com aqueles que exerciam as suas funções em um local de trabalho onde havia poucos funcionários e com aqueles que possuíam um tipo diferenciado de especialização (1992, p. 14). A despeito das garantias legais, entretanto, outra pesquisa mostrou que o gozo da licença tem outros custos tanto para os homens como para as mulheres, sendo os custos para os homens, medidos na forma de aumentos salariais, bem maiores (Sundström e Stafford, 1994).

22 Para uma crítica feminista ao sistema sueco de licença para os pais, ver Kaul, 1991 e Widerberg, 1991.

23 Note, entretanto, que, se a participação das mães no mercado de trabalho se tornou corriqueira, para muitas famílias o fator determinante é menos a "ideologia" do que a economia familiar. "Duas rendas são necessárias para se permanecer acima da linha de pobreza [...] para a maioria das famílias suecas" (Sandqvist, 1992, p. 83).

24 Tem tido grande visibilidade internacional o impacto da intervenção governamental e do ativismo de distintos grupos na redução das disparidades salariais e no incremento da participação feminina no universo político e sindical.

\section{BIBLIOGRAFIA}

ANDERSSON, A-K et al. (1992), "Taxes and labor supply: Dutch and Swedish women". Memorandum, 164, Department of Economics, Gothenburg University.

BAUDE, Annika. (1979), "Public policy and changing family patterns in Sweden, 19301977", in J. Lipman-Blumen \& J. Bernard (eds.), Sex roles and social policy: a complex social science equation, Londres, Sage.

BJÖRNBERG, Ulla. (1993), "Political parenthood among women and men in Sweden", in "Politics: a power base for women?", Örebro Women's Studies, 3, Örebro University, pp. 5-30.

EDLUND, J.; SUNDSTRÖM, E. \& SVALLFORS, S. (1994), Attitudes towards family and gender roles: a Swedish survey. Umeå, Umeå University, Department of Sociology.

FARIA, Carlos Aurélio P. (1998a), “A criança entre o Estado, o mercado e a família: o sistema sueco de creches em uma perspectiva comparada”. Dados, 41 (2): 283-335.

(1998b), "Uma genealogia das teorias e modelos do Estado de bem-estar social”. BIB - Revista Brasileira de Informação Bibliográfica em Ciências Sociais, 46: 38-71. 
(1997), "A questão populacional e a conformação do Estado de bem-estar na Suécia”. Revista Brasileira de Estudos Populacionais - IPEA/IBGE, 14 (1/2): 73-95.

(1996), "Crise na social-democracia sueca: a dissolução de velhas lealdades". Dados, 39 (2): 279-314.

FOLKSAM. (1995), Vår Trygghet, 1995. Stockholm, Folksam Förlagsservice.

GUSTAFSSON, Siv. (1990), "Separate taxation and married women's labor supply: a comparison of West Germany and Sweden". Research Memorandum, 9016, Department of Economics, University of Amsterdam.

. (1984), "Equal opportunity policies in Sweden", in Günter Schmid \& Renate Weitzel (eds.). (1984), Sex discrimination and equal opportunity: the labor market and employment policy, Nova York, St. Martin's Press.

HAAS, Linda. (1981), "Domestic role sharing in Sweden". Journal of Marriage and the Family, 43 (4): 957-967.

HOBSON, Barbara. (1993), "Feminist strategies and gendered discourses in welfare States: married women's right to work in The United States and Sweden", in S. Koven \& S. Michel (eds.), Mothers of a new world: maternalist politics and the origins of the Welfare State, Nova York, Routledge.

HOEM, Britta. (1993), "The compatibility of employment and childbearing in contemporary Sweden". Acta Sociologica, 36 (2): 101-120.

HOEM, Jan M. (1993), "Public policy as the fuel of fertility: effectts of a policy reform on the pace of childbearing in Sweden in the 1980s". Acta Sociologica, 36 (1): 19-31.

(1990), "Social policy and recent family change in Sweden". Population and Development Review, 16 (4): 735-748.

HWANG, Carl P. (1987), "The changing role of Swedish fathers", in Michael E. Lamb (ed.), The father's role: cross-cultural perspectives. Hillsdale, New Jersey, Lawrence Erlbaum Associates.

JONUNG, Christina. (1984), "Patterns of occupational segregation by sex in the labor market”, in G. Schmid \& R. Weitzel (eds.), Sex discrimination and equal opportunity: the labor market and employment policy. Nova York, St. Martin's Press.

JUSTER, F. T. \& STAFFORD, F. (1991), "The allocation of time: empirical findings, behavioral models, and problems of measurement". Journal of Economic Literature, 29: 471-521.

KAUL, HjØrdis. (1991), "Who cares? Gender inequality and care leave in the Nordic Countries". Acta Sociologica, 34 (2): 115-125.

LEWIS, J. \& ÅSTRÖM, G. (1992), "Equality, difference, and the State Welfare: labor market and family policies in Sweden". Feminist Studies, 18 (1): 59-87.

LILJESTRÖM, Rita. (1978), "Sweden", in S. B. Kamerman \& A. J. Kahn (eds.), Family policy: government and families in Fourteen Countries, Nova York, Columbia University Press.

LINDENCRONA, Gustaf. (1989), "Från Sam-till Särbeskattning. En Studie i Skatterätt och Jämställdhet”, in Öpnna Föreläsningar $i$ Juridik. Höstterminen 1988-1989. Stockholm, Juridiska Fakulteten i Stockholm, Skriftserien, 22: 19-37.

LIPMAN-BLUMEN, Jean \& BERNARD, Jessie. (eds.)(1979), Sex roles and social policy: $a$ complex social science equation. Londres, Sage.

LÖFSTRÖM, Åsa \& GUSTAFSSON, Siv. (1990), "Policy changes and women's wages in Sweden". Umeå Economic Studies, 232, University of Umeå.

MOEN, Phyllis. (1989), Working parents: transformations in gender roles and public policies in Sweden. Londres, Adamantine Press. 
NORDIC COUNCIL of MINISTERS. (1994), Women and men in the Nordic Countries. Copenhagen.

NÄSMAN, Elisabet. (1992), "Parental leave in Sweden: a workplace issue?". Stockholm Research Reports in Demography, 73, Stockholm University, Demography Unit.

OECD. (1995), "Long-term leave for parents in OECD countries", in OECD, Employment Outlook. Paris, pp. 171-200.

RIKSFÖRSÄKRINGSVERKET (1993), Vilka Pappor Kom Hem?. Statistisk Rapport Is-R, 3. Stockholm, RFV.

SANDQVIST, Karin. (1987), "Swedish family policy and the attempt to change paternal roles", in C. Lewis \& M. O'Brien (eds.), Reassessing fatherbood: new observations on fathers and the modern family. Londres, Sage.

. (1992), "Sweden's sex-role scheme and commitment to gender equality", in S. Lewis et al. (eds.), Dual-earner families: international perspectives, Londres, Sage.

SCHMID, Günter \& WEITZEL, Renate (eds.). (1984), Sex discrimination and equal opportunity: the labor market and employment policy. Nova York, St. Martin's Press.

STATISTISKA CENTRALBYRÅN. (1994), Att Klara av. Arbete, Barn, Familj. Stockholm, SCB. (1995), Women and men in Sweden: facts and figures, 1995. Örebro, SCB.

SUNDSTRÖM, Marianne. (1991), "Sweden: supporting work, family and gender equality", in S. B. Kamerman \& A. J. Kahn (eds.), Family policy: government and families in Fourteen Countries, Nova York, Columbia University Press.

. (1993), "The growth in full-time work among Swedish women in the 1980s". Acta Sociologica, 36 (2): 139-150.
(1996), "Determinants of the use of parental leave benefits by women in Sweden in the 1980s". Scandinavian Journal of Social Welfare, 5 (2): 76-82.

SUNDSTROM, M. \& STAFFORD, F. P. (1992), "Female labour force participation, fertility and public policy in Sweden". European Journal of Population, 8: 199-215.

(1994), "Time out for childcare and career wages of men and women". Stockholm Research Reports in Demography, 85, Stockholm University.

WIDERBERG, Karin. (1991), "Reforms for women - on male terms - the example of the Swedish legislation on parental leave". International Journal of the Sociology of Law, 19: 27-44. 


\section{ENTRE MARIDO E MULHER, O ESTADO METE A COLHER: RECONFIGURANDO A DIVISÃO DO TRABALHO DOMÉSTICO NA SUÉCIA}

Carlos Aurélio Pimenta de Faria

\section{Palavras-chave}

Igualdade de gênero; Licença maternidade; Trabalho não remunerado; Suécia.

$\mathrm{O}$ artigo tem por objetivo discutir o impacto de algumas políticas implementadas pela social-democracia sueca, ao longo das últimas décadas, com o propósito de facilitar o ingresso e a permanência das mulheres no mercado de trabalho além de fomentar a igualdade de gênero no país. Primeiramente, discute-se o impacto da legislação de 1971, que baniu a tributação conjunta dos casais, tornando compulsórias as declarações de renda individuais, o que, dado o sistema tributário altamente progressivo do país, implicou o estabelecimento de claros incentivos econômicos para que as mulheres participassem do mercado de trabalho. Além disso o artigo enfoca o chamado "sistema sueco de seguridade para os pais", um conjunto de direitos e benefícios estruturados com o intuito de minimizar as incompatibilidades entre as exigências do universo do trabalho remunerado e aquelas relacionadas à criação dos filhos. São discutidas com maior ênfase as peculiaridades e as formas de utilização efetiva da licença remunerada para os pais quando do nascimento de uma criança.

\section{BETWEEN HUSBAND AND WIFE THE STATE INTER- VENES: REDRAWING THE DIVISION OF DOMESTIC WORK IN SWEDEN}

Carlos Aurélio Pimenta de Faria

\section{Keywords}

Gender equality; maternity leave; unpaid work; Sweden.

The article aims to discuss the impact of some policies implemented by the Swedish social-democratic state in the the last decades with the purpose of facilitating the entrance and permanence of women in the labor market besides fomenting gender equality in the country. Firstly, it is discussed the impact of the 1971 legislation that banned taxation for couples, turning compulsory individual declarations of income, which, given the highly progressive tributary system of the country, implied the establishment of clear economic incentives for the participation of women in the labor market. Besides, the article focuses the so called "Swedish system for parents security", a set of structured rights and benefits aimed at minimizing the incompatibilities between the demands of the paid work universe and those related to a child's upbringing. The emphasis is on the peculiarities and effective forms used by parents concerning this paid license after the child's birth.

\section{L'INTERVENTION DE l'ÉTAT AU SEIN DU COUPLE: RESTRUCTURATION DE LA DIVISION DU TRAVAIL DOMESTIQUE EN SUÈDE}

Carlos Aurélio Pimenta de Faria

\section{Mots-clés}

Égalité de genres; Arrêt maternité; Travail non rémunéré; Suède.

Le but de cet article est de discuter l'impact de certaines politiques mises en place par les sociaux démocrates suédois au long des dernières décennies, afin de faciliter l'accès et la permanence des femmes dans le marché du travail et promouvoir l'égalité des sexes dans les pays. Dans un premier temps, nous abordons l'impact de la législation de 1971, qui a banni l'imposition conjointe des couples et a rendu obligatoire les déclarations d'impôts individuelles. Cela implica, à cause du système tributaire hautement progressif du pays, dans l'établissement de subventions économiques pour que les femmes participent au marché du travail. Par ailleurs, l'article aborde la question du "système suédois de sécurité sociale pour le pays ", relatif à un ensemble de droits et de bénéfices structurés dans le but de minimiser les incompatibilités entre les exigences de l'univers du travail rémunéré et celles relatives à l'éducation des enfants. Les particularités et les formes d'utilisation effective de l'arrêt rémunéré pour les parents lors de la naissance d'un enfant sont également abordées. 